\title{
Students' Attitudes on Electronic English Learning
}

\author{
Yosieka Maharani ${ }^{1}$, Dedi Rahman Nur ${ }^{2}$ \\ Universitas Widya Gama Mahakam Samarinda, Indonesia \\ Email Correspondence: d.blues84@gmail.com
}

\begin{abstract}
Along with the development of technology in various aspects of life, technology has a significant impact and influence in today's life. One of the roles of technology in learning activities is to support the learning activities more manageable to accomplish and exciting in the educational sector. One of the developments of technology in the education sector is E-Learning. E-Learning may be an option to be used in class as a learning tool. Especially on English subject when some students may find it difficult, E-Learning could be their alternative to learn English the significance of this study to find out the students' perspective regarding E-Learning in English. The data will be conducted by distributing a questionnaire to students. The objectives of this study are to find out attitudes from students toward E-Learning. The study was conducted in Bunga Bangsa Islamic Junior High School involving 56 students. A questionnaire was used as an instrument to collect the data, which score analyzed based on the mean score. The result showed students have positive attitudes toward E-Learning. In terms of students' attitudes, it is found that students have positive attitudes toward E-Learning since they found E-Learning is appropriate to use, effective, and excellent technique to help them learn English.
\end{abstract}

Keywords: Belief; E-Learning; attitudes

DOI

\begin{tabular}{l|l|l|}
\hline Received & $:$ & December 2020 \\
\hline Accepted & $:$ & January 2021 \\
\hline Published & $:$ & February 2021 \\
\hline $\begin{array}{l}\text { Copyright and } \\
\text { License }\end{array}$ & $\begin{array}{l}\text { Authors retain copyright and grant the journal right of first publication with the } \\
\text { work simultaneously licensed under Creative Commons Attribution 4.0 International }\end{array}$ \\
\hline License that allows others to share the work with an acknowledgment of the work's \\
authorship and initial publication in this journal.
\end{tabular}




\section{INTRODUCTION}

Technology plays an important role on daily basis today. It can not be separated from people because technology always involve on their life. Technology always grow up rapidly every day, it creates an efficient and effortless on people activities. The word technology comes from the Greek word "techno" which means the willingness, skills, knowledge of the way, rule, skill, tools and "logos" which means science, word, learning, mental state (Stosic, 2015).Technology in today's world touches, influences and shapes every aspect of human life. It is used on office space, education, entertainments and the way of life surviving (Ahmad \& Nisa, 2016). Along with the growth of technology, all of aspects on today activities easy to be accomplished as well as on educational sector. Technology support teacher to create learning environment turn into interesting and convincing students on learning activities. One of the outputs of development technology is an Electronic learning or E-Learning. E-Learning could define as an application of technology on educational sector. E-Learning applied existing technology to be used on learning activities in order to provide different learning variation on the class. E-learning could be effective and useful in the education world (Khan \& Arabia, 2016).

According to Jain (2014) in general, attitudes divided into three components; Affective components, Behavioral components, and Cognitive components. Affective. First, affective component is an emotional reaction whether they like or dislike it toward an attitude object. This component shows the emotional attitude that collaborates with cognitive processes. Second, behavioral component means component that concerns the behavior of an individual toward attitudes. Third, cognitive component refers to individual's opinion toward what he believed.

E-learning is the use of Internet technologies to improve knowledge and performance (Jethro, Grace, \& Thomas, 2012). According to Arkorful \& Abaidoo (2014) E-learning imply to the use of information and communication technologies that supply online resources. It can be explained as the use, delivery and achievement of learning, training or education electronically (Khan \& Arabia, 2016). E-Learning involve all forms of electronic which supported learning and teaching (Yacob, Zuriyati, Kadir, Zainudin, \& Zurairah, 2012). Moreover Nyagorme et al (2017) stated E-Learning well-known as a virtual class, WebBased Training, Computer-Based Training, and Mobile Learning. In addition, Luaran, Samsuri, Nadzri, Baharen, \& Rom, (2014) stated that E-learning engage the Internet, computers, networking and multimedia technologies. According to Gaur (2015) The 
application of E-learning divided into two major types such as full online learning and blended learning. Full online learning take place fully on E-Learning tools.

In addition, a research conducted by Cai (2012) explain the advantages of E-Learning are internet provide so many teaching resources in all field of topics such as information, text, audio, picture. It also provides effortless information at affordable costs. If the learner wants to find something, they just have to search it through internet. E-learning also provide easy access to English newspapers, articles, news, events, or something that interest them. Due to this benefit, E-Learning allow students to learn English everywhere and every time. In other hand, a research conducted by (Kisanga, 2016) stated the disadvantages of E-Learning divided into two variables; independent variable and external variable. The independent variable is teacher readiness, experience, qualification and academic background toward ELearning. The external variable may influenced by real life situation, infrastructure challenges, financial factors, and some technical reasons.

According from several studies, students are aware on the implementation of ELearning and prefer the usage of technology in their study. Also, E-Learning increase students' motivation to learn. It can be said that technology bring a positive impact to education. In addition, students' attitude toward technology is positive considering many benefits offered by technology. To know students' attitudes is important. It will show how students respond, react, and feel toward E-learning. After knowing their attitudes, the researcher expected this study could be a considerable for teacher to involve E-Learning and still considered the students attitudes on E-Learning on English subject.

One of the subjects that teacher may find the issue to teach is English subject. It has become common problem faced by people from non-English speaking countries (Thongmak, 2013). Students already feel down before the class begin by saying English is difficult. Then, it is a challenge for teacher to create an excitement atmosphere on the class by involving ELearning. If the teacher and students are aware of the importance of E-Learning in English language learning, English learning is expected to be more fun and easier. Based on the reason above, the researcher would like to conduct a study about Students' and Teachers' Attitudes on Electronic English learning to investigate their attitudes toward E-Learning.

\section{METHODOLOGY}

According to Cresswell (2015) research design is used to gather, analyze, and interpret data using qualitative or quantitative research. This study applied descriptive study as the research design. Descriptive study is a study to explore or describe some phenomenon 
without any manipulation or give a treatment. Descriptive study is a method that aim to gather the actual information that already done. It does not give a treatment, manipulation or modify variable but only describe it as it is. It is the simplest research compared to other studies. This study conducted with quantitative approach. According to Gay, Mills, \& Airasian (2012) quantitative approach is using numerical data to describe, clarify, predict to be collected and analyzed. The data will be collected by using questionnaire. The steps to conduct the data are:

1) Construct the questionnaire before distribute it to students. To construct the questionnaire, the researcher collect some information from previous studies, journals and books from experts.

2) Distribute questionnaire to respondents.

3) Tabulation the data by input the data into tabulation table so that it will easier to process and analyze.

4) Process the data by using mean analysis to find out the average score of students' beliefs to E-Learning

\section{FINDINGS}

This study will be divided into two types based on the questionnaire for attitudes and preferences. First, it will be explained the student's attitudes on Electronic English Learning, and the second will be explained the students' preferences on Electronic English Learning

\subsection{The Students Attitudes on Electronic English Learning}

\begin{tabular}{llll}
\multicolumn{2}{l}{ Table 1. Students' Attitudes on Electronic English Learning } & Score & \\
\hline No & Parameter & 3.63 & \\
\hline 1 & I eager to learn English with E-Learning & 4.11 & \\
2 & I choose to use online learning to study English & 4.18 \\
3 & In my opinion, using E-Learning is needed when learn English & 3.76 \\
4 & I agree that technology support English learning & 4.13 \\
5 & In my opinion, E-Learning is more efficient for learning English & 4.24 \\
6 & Multimedia is one of practical approach for me & 4.24 \\
7 & My English skill rise after practice softwares or apps & 3.58 \\
8 & English videos triggered me to gain more vocabulary & 3.71 \\
9 & My writing skill get better by using social network & \\
10 & I gain listening skill by using musics &
\end{tabular}

it can be seen the highest average scores are on item numbers (7) and (8). Students rise their English skill by practicing with software or apps and English videos increase their vocabulary. Second, students agree that technology support their learning activities. In addition, students also use multimedia as an practical approach for learning English. Moreover, students perspective stated ELearning is appropriate to use and students eager to learn English with E-Learning. In addition, 
students opinion to E-Learning is it is efficient to them. However, students gain their listening skill by using musics. In other hand, not many students choose online learning in their English study and students barely use social network to raise their writing skill.

\subsection{The Students' Preferences on Electronic English Learning}

Table 2. Students' Attitudes on Electronic English Learning

\begin{tabular}{rlll}
\hline No & Parameter & Score \\
\hline 1 & Technology could enhance my English skill & 4.08 & \\
2 & Smartphones or tablets could support my language skill & 4.16 & \\
3 & Social media could rise my conversation and reading skill & 4.05 & \\
4 & I could speak in English because of platform such as Youtube & 4.16 & \\
5 & I could write in English through Ms.Word & 3.78 & \\
\hline
\end{tabular}

On the table, mostly students language skill develop because it is supported by smartphones or tablets also platform such as Youtube which it could enhance their speaking skills. In addition, this situation occurs because mostly students use technology in their English learning. Besides, some of students use social media which allow students to communicate with others such as Facebook, Twitter, etc to increase their skill in English. In other hand, some students write in English through Ms.Word to develop their writing skill.

\section{DISCUSSION}

Mostly students believe that multimedia such as computer or YouTube is better alternative technique to learn English. Thus, it can be said students already realize that technology could improve their English ability. Moreover, English language software or apps could increase their creativity and by watching online videos could increase their vocabulary. However, only some students believe that E-Learning tools are effective to increase their English skills. In addition, students somewhat enjoy using E-Learning on their learning activities so that it can be said using E-Learning is necessary in learning English. In other hand, not many students using online learning, social networking sites and voice recorder to improve their English skills. To summarize, mostly students has positive attitudes toward ELearning. They are aware that the development of technology could help them improve their skills in English by learning it through online audio or video or using English software. 


\section{CONCLUSION}

Mostly students have positive attitudes toward E-Learning or technology in their English learning. Students perceive technology as a medium that can be used to improve their ability to learn English. Based on the result of questionnaire above, it can be seen that students accept the development of technology could be used in learning activities.

\section{REFERENCES}

[1] Ahmad, S. R., \&Nisa, M. U. (2016). The Significance of Educational Technology in Teaching Learning process. 4(1).

[2] Arkorful, V., \&Abaidoo, N. (2014). The Role of E-Learning, The Advantages and Disadvantages of Its Adoption in Higher Education. International Journal of Education and Research, 2.

[3] Cai, H. (2012). E-learning and English $\quad$ Teaching, $\quad 2, \quad 841-846$. https://doicrg/10.1016/j.ieri.2012.06.180

[4] Chowdbury, S. K., \& Salam, M. (2014). Predecting Attitude Based on Cognitive, Affective, and Conative Components: An Online Shopping Perspective.

[5] Cresswell, J. W. (2015). Educational Research, Planning, Conducting, and Evaluating Quantitative and Qualitative Research (fifth edit). United States of America: Pearson Education, Inc.

[6] Gaur, P. (2015). Research Trends in E-Learning. Media Conmmunique

[7] Gay, L. R., Mills, G. E., \&Airasian, P. (2012). Educational Research: Competencies for Analysis and Applications (10th ed.). Boston: Pearson.

[8] Jain, V. (2014). 3d Model of Attitude

[9] Jethro, O. O., Grace, A. M., \& Thomas, A. K. (2012). E-Learning and Its Effects on Teaching and Learning in a Global Age. 2(1), 203-210.

[10] Khan, I. A., \& Arabia, S. (2016). Effectiveness of E-learning for the Teaching of English : A Study of Comparative Strategies, 7(3). https://doi.org/10.7575/aiac Ells.v.7n.3p.1 25

[11] Kisanga, D. H. (2016). Determinants of Teachers Attitudes Towards E - Learning in Tanzanian Higher Learning institutions, 17(5)

[12] Nyagorme, P., Qua-enoo, A. A., Bervell, B., \&Arkorful, V. (2017). The Awareness and Use of Electronic Learning Platforms: A Case of a Developing Country. (July). https://doi.org/10.13189/wjcat.2017.05020

[13] Soliman, N. A. (2014). Using E-Learning to Develop EFL Students Language Skill and Activate Their Independent Learning, (june), 752-757.

[14] Stosic, L. (2015). The Importance of Educational Technology in Teaching. (June). 
[15] Thongmak, M. (2013). Social Network System in Classroom: Antecedents of Edmodo (C) Adoption. 2013. https://doi.org/10.5171/2013.657749

[16] Yacob, A., Zuriyati, A., Kadir, A., Zainudin, O., \&Zurairah, A. (2012). Student Awareness Towards E-Learning In Education. Procedia - Social and Behavioral Sciences, 67(November 2011), 93-101. https://doi.org/10.1016/j.sbspro.2012.11.310 